\title{
NOTICE OF REDUNDANT (DUPLICATE) PUBLICATION
}

The paper "Improving Safety at Sea through Compliance with International Maritime Safety Codes", written by Jelena Nikčević Grdinić, was published in ToMS, Vol. 6 No. 2, pp. 130-139 (doi: 10.7225/toms.v06.n02.005) on 21st October, 2017, while it was published in the same form and with the same title in the Journal of Maritime Research Vol. 13, No. 1, pp. 5-14 on 28th October, 2017.

\section{COPE retraction guidelines}

"If redundant publication has occurred (i.e. authors have published the same data or article in more than one journal without appropriate justification, permission or cross-referencing) the journal that first published the article may issue a notice of redundant publication but should not retract the article unless the findings are unreliable. Any journals that subsequently publish a redundant article should retract it and state the reason for the retraction".

URL: https://publicationethics.org/files/retraction\%20guidelines $0 . p d f$ 


\title{
Improving Safety at Sea Through Compliance with International Maritime Safety Codes
}

\author{
Jelena Nikčević Grdinić
}

There is a number of international instruments that contribute to the improvement and advancement of safety at sea. The primary task of all international instruments is to make sea navigation less dangerous and to reduce, to the maximum extent possible, the risks associated with maritime navigation, and hence the occurrence of maritime accidents and marine pollution. In addition to international conventions as basic international instruments, codes adopted by various international organizations are of particular importance for improving the safety of navigation. The IMO, as the main organization responsible for improving maritime safety, certainly occupies a special place. Since its inception, the IMO has convened many international conferences and developed many regulations, recommendations and codes of practice concerning the carriage of dangerous cargoes by sea. Thirty conventions and protocols, as well as a number of codes and recommendations concerning maritime safety, the prevention of marine pollution and other related matters have been adopted by the IMO. In this paper we have tried to point out the most important international codes the observance of which is imperative for improving safety at sea. Attention is paid to the role of a number of international organizations in the safety of navigation, with special emphasis on the IMO.

\section{KEY WORDS}

$\sim$ Safety of navigation

$\sim$ Safety

$\sim$ International instruments

$\sim$ Codes

University of Montenegro, Maritime Faculty Kotor, Kotor, Montenegro e-mail: jelenag@ac.me

doi: 10.7225/toms.v06.n02.005

This work is licensed under (cc) BY

\section{THE NECESSITY OF ACCEPTANCE OF INTERNATIONAL INSTRUMENTS ON MARITIME SAFETY}

The entire maritime law is more or less codified by a number of international conventions intended to be ratified and incorporated by the states into their national legal systems. Pursuant to Article 26 ("Pacta sunt servanda") of the Vienna Convention on the 1969 Law of Treaties "... every treaty in force is binding upon the parties to it and must be performed by them in good faith." This means that the contracting states are required to incorporate convention provisions into their national legislation and ensure the proper observance of standards in line with the actions of other states. In fact, international conventions are integrated into domestic law or, as professor Grabovac points out the "nationalization of international regulations" is carried out. ${ }^{1}$ International norms integrated into the legal systems of national states form a distinct legal system of regulations distinguishable both from the Continental and the Anglo-Saxon legal systems, and may thus be considered to be the third legal system in the world. ${ }^{2}$ Why do international maritime regulations need to be nationalized with respect to other branches of the law? The answer lies in three facts. First, it is clear that navigation is virtually the same everywhere and international regulations help prevent the co-existence of disparate legal regulations capable of potentially jeopardizing the safety of shipping. International regulations liberate the international shipping industry from having to cope with contradictory national safety regulations on

1. Grabovac l. (2009) International contracts as the basis for harmonizing maritime law - in relation to the Act on Amendments to the Maritime Code, 2008, Collection of Works of the Faculty of Law in Split, Vol. 46 (2), pp. 261 - 269.

2. Bolanča, D. (2002) Maritime Law In the Era of Globalisation-Universal Law or A Mixed Legal System? Zbornik radova Pravnog fakulteta u Splitu, 67(3-4), pp. 333338. 
the construction and operation of vessels. And last but not least, international conventions proscribe minimum standards for the regulation of competition between states.

Regulations on maritime safety, by nature, regulate maritime navigation identically in all countries. This issue is regulated by international instruments each country is required to strictly observe and consistently apply. Many international instruments, like international conventions, resolutions, codes, guidelines and regulations have been issued in this respect. The provisions of paragraph 3, Article 94 of the UNCLOS Convention of 1982, indicating the general obligations of the flag state ${ }^{3}$ regarding the safety of navigation, clearly state that "... every state shall take such measures for ships flying its flag as are necessary to ensure safety at sea with regard, inter alia, to: (a) the construction, equipment and seaworthiness of ships; (b) the manning of ships, labour conditions and the training of crews, taking into account the applicable international instruments; (c) the use of signals, the maintenance of communications and the prevention of collisions." Paragraph 4 states that "...such measures shall include those necessary to ensure: (a) that each ship, before registration and thereafter at appropriate intervals, is surveyed by a qualified surveyor of ships, and has on board such charts, nautical publications and navigational equipment and instruments as are appropriate for the safe navigation of the ship; (b) that each ship is in the charge of a master and officers who possess appropriate qualifications, in particular in seamanship, navigation, communications and marine engineering, and that the crew is appropriate in qualification and numbers for the type, size, machinery and equipment of the ship; (c) that the master, officers and, to the extent appropriate, the crew are fully conversant with and required to observe the applicable international regulations concerning the safety of life at sea, the prevention of collisions, the prevention, reduction and control of marine pollution, and the maintenance of communications by radio..." Paragraph 5 of the same Article states that in taking the measures called for in the preceding paragraphs "... each State is required to conform to generally accepted international regulations, procedures and practices and to take any steps which may be necessary to secure their observance."

Consequently, no state has the discretion to independently decide on these issues. In fact states, as a rule, adopt international regulations in this field. However, this is not to say that the states are prohibited from bringing their national legislations,

3. Flag state is the state the flag of which the ship is flying, or the state of ship's registration. The flag of the vessel is the element of individualization of the vessel which indicates her nationality. Each state independently determines the requirements a vessel must meet to receive its nationality or earn the right to fly its flag. The requirements should establish the genuine link between the ship and the flag. The flag state has legislative and executive authority over the vessel flying its flag. However, when the vessel arrives in the coastal belt, which is under the sovereignty of another state, it comes under the jurisdiction of that coastal state. merely that they are required to do so in strict compliance with international regulations. ${ }^{4}$

\section{THE ROLE OF INTERNATIONAL ORGANIZATIONS IN THE SAFETY OF NAVIGATION}

Although a number of international organizations contribute to maritime safety by preparing international conventions, the IMO (International Maritime Organization) stands out as the most important, followed by the ILO (International Labour Organization) and the UNCTAD (United Nations Conference on Trade and Development), and from regional organizations, the EMSA (European Maritime Safety Agency). There are also other non-governmental organizations, institutions and associations whose members perform navigational activities and various other activities directly or indirectly related to maritime safety. ${ }^{5}$

The ILO is a specialized UN agency, founded in 1919, which adopted a large number of conventions and recommendations, inter alia, relating to the working and living conditions of sailors. The Maritime Labour Convention, MLC from 2006, laying down the minimum requirements for work onboard, conditions of employment, wages, hours of work and rest and medical care, is certainly worth a mention.

Established in 1964 with seat in Geneva, the UNCTAD is a permanent body of the United Nations General Assembly for trade and development. The primary objective of UNCTAD is to define the rules that apply to all aspects of development, including transportation. The UNCTAD Committee on Shipping is specifically responsible for the commercial and economic aspects of maritime affairs. Magazine Review of Maritime Transport, published annually from 1968, significantly contributed to

4. Each country has its own national regulations (acts and bylaws) on the safety of navigation which must fully comply with international regulations. In Montenegro, the main piece of legislation governing this subject matter is the Act on Safety of Maritime Navigation of 2013 ("Official Gazette of Montenegro", No. 62/2013).

5. These are different organizations: Ship-owners Associations - ICS (International Chamber of Shipping International Chamber of Shipping), INTERTANKO (International Association of Independent Tanker Owners), INTERCARGO (International Association of Dry Cargo Shipowners), BIMCO (Baltic and International Maritime Council), ISMA (International Security Management Association); Seafarers Associations - ITF (International Transport Workers' Federation), IFSMA (International Federation of Shipmasters' Associations), IMPA (International Maritime Pilots' Association); Shippers and Cargo Owners Associations - OCIMF (Oil Companies International Marine Forum), CEFIC (European Chemical Industry Council); Insurers Associations - IUMI (International Union of Marine Insurance), IG P\&I Clubs (International Group of P\&I); Regulatory Organizations and Classification Societies - IACS (International Association of Classification Societies), ISO (International Organization for Standardization), IEC (International Electrotechnical Commission); Ports,Terminals and Port Services Associations - IAPH (International Association of Ports and Harbors), SIGTTO (Society of International Gas Tanker \& Terminal Operators) and Navigational Services Associations different organizations that provide navigation services - IALA (International Association of Marine Aids to Navigation and Lighthouse Authorities). 
maritime safety. The publication analyzes the changes in the maritime trade and port sector, and presents them through corresponding statistical information.

The EMSA, based in Lisbon, was established in 2002 following a major maritime accident of tanker Erica, to contribute to the safety of maritime navigation in the European Union by introducing a number of measures and actions aimed at reducing the risk of maritime accidents, preventing pollution caused by ships and safeguarding human lives at sea. The EMSA has an important role in assisting EU candidate countries (with the implementation of regulations into their national legislations) with issues relating to maritime safety and marine pollution prevention.

\subsection{IMO and Safety of Navigation}

The role of the IMO was defined in Article 2 of the Convention on the International Maritime Organization (IMO Convention) adopted in Geneva, Switzerland, on 6 March 1948, which entered into force on 17 March $1958^{6}$. Article 1 of the IMO Convention sets out the purposes of the Organization and establishes the global scope of IMO's safety and antipollution activities. It also refers to other tasks, such as the promotion of efficiency of navigation and the availability of shipping services based on the freedom of shipping of all flags to take part in international trade without discrimination. Article 2 states that the IMO shall: "...a) consider and make recommendations upon matters"(within its attributions), "... b) provide for the drafting of conventions ..., and recommend these to governments... and convene such conferences as may be necessary"..."c) provide machinery for consultation among Members and the exchange of information among Governments..."

Almost 50 international conventions and hundreds of guidelines and codes have been adopted under the auspices of the IMO. These instruments are constantly refined and updated, and constitute the regulatory framework of international shipping.

The vast majority of IMO international conventions are in force, and several are widely if not universally accepted. Additionally, they cover almost all the world fleet tonnage to which they apply. Today it is virtually impossible for a ship to sail, unless its flag State is party to the principal IMO conventions.

The IMO governing bodies are the Assembly, which convenes every two years and is open to participation by all Member States, and the Council, which convenes every

6. Article 74 of the IMO Convention reads as follow: "... The present Convention shall enter into force on the date when 21 States, of which seven shall each have total tonnage of not less than 1,000,000 gross tons of shipping, have become parties to the Convention in accordance with Article 71..." six months. The Council is the only elected body and has 40 members. ${ }^{\text {? }}$

The technical and legal work of the Organization is carried out by committees and sub-committees, which are open to participation by all members. Intergovernmental and nongovernmental organizations, with specific competences and know-how, take active part in the work of the Organization. Committees meet at regular intervals, on average every six months.'The main committees are the Maritime Safety Committee (MSC), the Marine Environment Protection Committee (MEPC), the Legal Committee (LC), the Facilitation Committee (FC) and the Technical Co-operation Committee (TCC). In order to be implemented, the international conventions adopted by the IMO must be ratified by the states and incorporated into their national legislations. From the legal perspective, it is then up to the national administrations to make sure that ships flying their flags comply with the requirements contained in the IMO treaties and non-treaty instruments. Nonetheless, the IMO, using various techniques, actively encourages flag States to take the necessary implementing actions.

The IMO international conventions can be broadly divided into three main groups: those concerning the safety of navigation, those dealing with preventing and combating marine pollution, and those regulating liability and compensation issues and other legal matters. In more recent years, security has also been the focus of IMO treaties.

\section{SAFETY CONVENTIONS ${ }^{8}$}

Some of the most important IMO conventions on the safety and security of navigation are the International Convention for the Safety of Life at Sea (SOLAS 1974), ratified by 163 states with the combined merchant fleet representing $99.14 \%$ of the world tonnage (the International Ship and Port Facilities Security Code (ISPS) was adopted in 2002 as an integral part of the SOLAS); the Load Lines Convention (LL 1966) ratified by 161 countries, with $99.13 \%$ of the world tonnage; the International Regulations for the Prevention of Collisions at Sea (COLREG 1972) ratified by 157 states, with $99.13 \%$ of the world tonnage; the Convention

7. The following states were Council members on the 2014-2015 biennium. Category a): 10 states with the largest interest in providing international shipping services: China, Greece, Italy, Japan, Norway, Panama, Republic of Korea, Russian Federation, United Kingdom, United States. Category b): 10 other states with the largest interest in international seaborne trade: Argentina, Bangladesh, Brazil, Canada, France, Germany, India, Netherlands, Spain, Sweden. Category c): 20 states not elected under (a) or (b) above which have special interests in maritime transport or navigation, and whose election to the Council will ensure the representation of all major geographic areas of the world: Australia, Bahamas, Belgium, Chile, Cyprus, Denmark, Indonesia, Jamaica, Kenya, Liberia, Malaysia, Malta, Mexico, Morocco, Peru, Philippines, Singapore, South Africa, Thailand, Turkey.

8. Nikčević Grdinić, J., (2015) Legal regulations in the function of ensuring ship safety, Pomorstvo: Scientific Journal of Maritime Research, Vol.29 No.1 pp. 34-38. 
on Standards of Training Certification and Watchkeeping for Seafarers (STCW 1978), with 162 member states and $99.18 \%$ of the world tonnage; and the Convention on Maritime Search and Rescue (SAR 1979), ratified by 111 countries with $80.176 \%$ of the world tonnage. ${ }^{9}$

Other important legal treaties from the domain of liability and compensation for damage at sea are the Convention on Limitation of Liability for Maritime Claims (LLMC 1976) and the Athens Convention on the Carriage of Passengers and their Luggage by Sea (PAL 1974). IMO legal treaties also include the International Convention on Salvage (Salvage 1989), the Convention for the Suppression of Unlawful Acts against the Safety of Maritime Navigation, (SUA 1988) and the Protocol for the Suppression of Unlawful Acts against the Safety of Fixed Platforms Located on the Continental Shelf 1988 (SUA PROT 1988). Both SUA and the Protocol were substantially amended by the IMO's Legal Committee following the events of 11 September 2001. The amendments were considered and adopted by an international legal conference convened by IMO 10-14 October 2005.

\section{SAFETY CODES}

In addition to international conventions, other legal instruments adopted by the IMO are also of importance for maritime safety. Different terminology is adopted for their identification. These are various resolutions, codes, standards, protocols, etc. on a variety of issues such as: design, construction and equipment of ships, ship stability, fire protection, radio communication and transportation of cargo (including dangerous goods), security management and maritime safety. These legal instruments differ from international conventions (containing principles, norms, standards or other statements of expected behaviour) and fall within the domain of soft law. ${ }^{10}$

A large number of codes on maritime safety was adopted under the auspices of the IMO. Codes on the safe transportation of cargo which regulate the safe transportation of cargo in detail are particularly important. In this respect, general codes, such as: the CSS Code (Code of Safe Practice for Cargo Stowage and Securing) and the IMSBC Code (International Maritime Solid Bulk Cargoes Code) are of special interest, as are the codes relating to the safe carriage of certain types of cargo, primarily the carriage of grain, timber and dangerous goods by sea. Examples of such codes are: the International Grain Code (International Code for the Safe Carriage of Grain in Bulk) and the Code of Safe Practice for Ships Carrying Timber Deck Cargoes. The most important codes

9. As per data as on 5 June 2017.

10. The notion of soft law designates rules which are not legally binding, as opposed to hard law denoting legally binding acts. However, this rule can not be applied strictly to codes adopted by the IMO, since special provisions of many international conventions call for their mandatory application. regulating the carriage of dangerous goods by sea are: the IMDG code (International Maritime Dangerous Goods), the IBC code (International Code for the Construction and Equipment of Ships carrying Dangerous Chemicals in Bulk), the IGC Code (International Code for the Construction and Equipment of Ships Carrying Liquefied Gases in Bulk) and the INF Code (The International Code for the Safe Carriage of Packaged Irradiated Nuclear Fuel, Plutonium and High Level Radioactive Wastes on Board Ships). The ISM code (International Management Code for the Safe Operation of Ships and for Pollution Prevention) adopted by the IMO to reduce the human factor risk, improve maritime safety and avoid maritime accidents is also worth a mention. ${ }^{11}$

\subsection{Code of Safe Practice for Cargo Stowage and Securing, the CSS Code}

The CSS Code was adopted by the IMO Assembly on 6 November 1991. The 74 CSS Code was adopted by Resolution A.714 (17). The application of CSS Rules, consolidating almost all IMO recommendations on cargo stowage, is mandatory since 1997. The CSS Code consists of 7 chapters and 14 annexes. It applies to ..."cargoes carried on board ships (other than solid and liquid bulk cargoes and timber stored on deck) and, in particular, to those cargoes whose stowage and securing have proved in practice to create difficulties." 12

Considering the specific matter dealt with in the Code, it was amended relatively early. The first significant amendment to the CSS code was made in $1994^{13}$, when Annex 13 on methods to assess the efficiency of securing arrangements for non standardized cargo was introduced. ${ }^{14}$ Amendments to Annex 12 on the safe stowage and securing of unit loads, were made by the MSC/Circ.740, in June 1996, followed by amendments to the CSS Code by the MSC in 2010. MSC.1/Circ.1352. These amendments include Annex 14: Guidance on Providing Safe Working Conditions for Securing of Containers on Deck. The objective of Annex 14 is to ensure safe working conditions, and in particular, access to safe and appropriate equipment to persons responsible for taking safety measures on containers transported on the deck of the ship.

11. Experience shows that the human factor, i.e. human error is one of the main causes of accidents at sea. When it comes to accidents and incidents at sea, except in rare cases of force majeure, human activity is almost always included. Oversights in ship management were the main causes of accidents. The human factor (error of the crew) is believed to have played a role in $75 \%$ to $96 \%$ of maritime accidents. Rothblum, A., Human Error and Maritime Safety, Maritime Human Factors Conference, Linthicum, MD, March 13-14., 2000.

12. Chapter 1 Article 1.1. of CSS Coda

13. MSC/Circ.691

14. In May 2002 important amendments were made in Annex 13, MSC/Circ 1026 Circular 1026 also includes an extension on the scope of application recommending all lashing assemblies to be fixed to strong or fixed points, a new table on friction coefficients and new texts on an advanced calculation method and an alternative method of balancing forces. 


\subsection{International Maritime Solid Bulk Cargoes Code, the IMSBC Code}

The IMSBC code is the basic code that regulates the transportation of bulk solids, although it does not apply to grain. It was published several times after its first publication in 1965. The IMSBC Code was originally called the Code of Safe Practice for Solid Bulk Cargoes BC Code. ${ }^{15}$ However, on 4 December 2008, the $\mathrm{IMO}^{16}$ adopted a new code for the carriage of solid bulk cargoes - the IMSBC Code. The primary objective of the IMSBC Code is to ensure the safe stowage and shipment of solid bulk cargoes, provide information on the dangers certain shipments are exposed to and instructions on procedures to be followed during their transportation. All ships are required to comply with the IMSBC Code, regardless of the date of keel laying and gross register tonnage. The IMSBC Code became mandatory on 1 January 2011. The BC Code continued to be applied between 1 January 2009 and 1 January 2011, during which period the IMSBC Code was applied on a voluntary basis. ${ }^{17}$ Both the IMSBC Code and the BC Code divide cargoes into three groups A, B, and C. More detailed requirements for each type of cargo are given in some parts of this paper. In June 2013, the IMO, namely the MSC, adopted Resolution 354 (92) laying down amendments to the IMSBC Code. Contracting parties of the SOLAS Convention were free to apply amendments in whole or in part from 1 January 2014 at their discretion, with their mandatory application starting as of 1 January 2015.

\subsection{International Code for the Safe Carriage of Grain in Bulk, International Grain Code}

The International Grain Code applies to grain. It was adopted in May 1991 and contains detailed regulations on the carriage of grain in bulk. Its application is mandatory. Each cargo ship carrying grain is required to comply with the requirements of the International Grain Code and have the documentation (approval) necessary for such carriage. A ship which does not have such a document can not be loaded with grain until the commander obtains such approval from the competent authorities or until the government of the country of the port of loading confirms that the ship meets the requirements of the International Grain

15. The BC Code provides guidelines for maritime administration, shipowners, shippers and other parties with respect to standards applied to safe stowage and carriage of solid bulk cargoes, excluding grains which are subject to specific rules. The primary purpose of the BC Code is to improve boarding and lodging of bulk cargoes by pointing out the dangers of loading, providing guidelines on procedures to be followed when loading bulk cargo, as well as the list of cargo regularly carried in bulk, description of testing procedures conducted to determine the properties of cargoes carried in bulk.

16. Resolution MSC.268 (85)

17. However, shipping companies are aware that the Port State Control and port authorities of many states require proof of compliance with the IMSBC Code, which should be available on board.
Code. The International Grain Code replaced Chapter VI of SOLAS 1974 , which regulated grain carriage in more detail.

\subsection{Code of Safe Practice for Ships Carrying Timber Deck Cargoes, TDC Code}

The TDC Code was adopted by the IMO in 1972 and amended in 1978. The introduction of new techniques and technologies in the maritime industry and the emergence of sophisticated ships necessitated Code revision. The new code was adopted at the IMO's seventeenth session in November 1991, by Resolution A.715(17), in response to continuous injuries and loss of human life when moving wood and frequent loss of wood transported as cargo. The new Code revised the TDC Code from 1972. During its adoption, special attention was paid to the construction of larger and more sophisticated ships, as well as to the introduction of new cargo handling techniques. The Code contains four chapters. Chapter 1 contains general provisions, Chapter 2 contains data on stability, Chapter 3 provisions on stowage and Chapter 4 provisions regulating the securing of timber deck cargoes. Although the TDC Code was directed primarily at providing recommendations for the safe transportation of wood on the deck, it also contains an appendix consisting of recommendations for the stowage of wood under the deck. The Code was amended by IMO Resolution A.1048-a (27), adopted on 30 November 2011.

\subsection{International Maritime Dangerous Goods, the IMDG Code}

The participants of the SOLAS conference held in 1960 decided to regulate the carriage of dangerous goods by new international regulations adopted by the IMO. In 1965, the IMO first published the IMDG Code, which became mandatory for all member states of the SOLAS Convention as of 1 January 2004. The IMDG Code is an international act for the carriage of dangerous goods by sea, regulating their packaging, transport in containers and stowage, with particular reference to the segregation of incompatible substances. This is a unique international Code, which comes in addition to the rules of the SOLAS Convention. Although it was adopted primarily for maritime carriage, it has a significant impact on other branches of carriage as well. This Code served as the basis for the adoption of pieces of legislation and recommendations for the carriage of dangerous goods. The IMDG Code was intended to advance the safety of carriage of dangerous goods, protect the marine environment and improve the free unlimited flow of dangerous goods with appropriate supporting documentation. ${ }^{18}$

18. Nikčević Grdinić, J., (2012) Safe Transport of Dangerous Goods by Sea, Import Part of the Maritime Transport, Proc.of the 5th International Conference on Maritime Transport, 27th-29th June, Barcelona, Spain, pp.1038-1056. 
Since the IMDG Code is regularly updated, it is constantly evolving and changing. However, its basic structure remains unchanged.

When it was amended, new dangerous goods were included, as well as new technologies and methods of operation or handling of dangerous goods. Cargoes listed in IMDG regulations are dangerous goods. However, if a particular cargo is not listed, it does not necessarily mean that it is not dangerous cargo. The states may extend the list of dangerous cargoes in their national legislations, including them in the regimen of dangerous goods. In addition, national legislations may proscribe extra requirements to be met by ships carrying dangerous goods when entering their ports. In any case, the existing national regulations must be based on the IMDG Code. Given the fact that certain states prohibit the carriage of certain dangerous goods through their territory or allow such a carriage, but in limited quantities, it is paramount for every shipping company to be familiar with the regulations of transit or destination countries of their ships. ${ }^{19}$

In May 2000, the MSC made amendments to the IMDG Code, which significantly changed its form. The changes came into force on 1 January 2001. Pursuant to the amendments, the IMDG Code now consists of seven parts, two appendices and an index. The parts of IMDG regulations are: Part 1 - General principles, definitions and training; Part 2 - Classification; Part 3 - Dangerous Goods List - DGL exceptions to the limited amounts. The DGL is the core of the IMDG Code and presents information on transport requirements in coded form; Part 4 - Packing and tank provisions; Part 5 - The consignment procedures; Part 6 - Construction and testing of packaging, medium sized bulk containers, large packaging, portable tanks and road cisterns; Part 7-Requirements relating to transport operations. Appendices to the IMDG Code are: Appendix A - list of generic goods and commodities that are not specified elsewhere and proper shipping names; Appendix $B$ - a brief glossary of terms.

According to the IMDG Code, dangerous goods are divided into nine classes: Class 1- Explosives substances and articles; Class 2- Gases, compressed, liquefied or dissolved under pressure; Class 3- Flammable liquids; Class 4- Flammable solids, liable to spontaneous combustion, or which, in contact with water, emit flammable gases; Class 5- Oxidizing substances (which provoke combustion) and organic peroxides which are subject to violent or explosive decomposition; Class 6- Toxic and infectious substances; Class 7- Radioactive materials; Class 8- Corrosive materials; Class 9- Miscellaneous dangerous substances and articles such as aerosols, some ammonium nitrate fertilizers, asbestos, safety matches and substances designed as marine pollutants. The purpose of the classification given in the

19. For example, the Port of Singapore is known for its sensitivity to the passage of ships with dangerous cargo and strict rules contained in its port acts (Port of Singapore Authority Act Code).
IMDG Code is to distinguish cargo potentially dangerous for transporting from that which is not; to identify risks associated with the transportation of dangerous goods; to identify measures necessary to effect the safe transportation of dangerous goods, without risk to people and property (during transportation, as well as during the stay in port and onboard).

In May 2002, amendments to Chapter VII of the SOLAS Convention were adopted, proscribing that the IMDG Code become binding for all member states of the SOLAS Convention as of 1 January 2004. In fact, although the IMDG Code is mandatory for all member states of the SOLAS Convention, from the legal standpoint, some of its provisions are formulated as recommendations. Specifically, the word "must" is quite frequently replaced with "must" in the Code.

\subsection{International Code for the Construction and Equipment of Ships carrying Dangerous Chemicals in Bulk, IBC Code}

The IBC Code defines international standards for the safe carriage by sea of dangerous and harmful liquid chemicals in bulk. In order to minimize the risks for the ships, the crew and the marine environment, the IBC Code sets out international requirements for the design and construction of ships, and proscribes the required equipment. The IBC Code is applicable to all tankers carrying chemicals, regardless of size. Risks associated with chemicals are indicated, such as: fire, threat to human health, pollution of the sea, air and the marine environment, reactions with other chemicals and water. The IBC Code requires the ships to be inspected and issued the international certificate for the carriage of dangerous chemicals in bulk. The international certificate contains the information on the type of the ship according to the Code, cargoes that can be carried, additional requirements, exemptions, etc. All dangerous liquids are classified into four categories: Category A - chemical substances that can cause considerable danger to marine resources and human health; Category B - substances that can cause certain dangers; Category C - substances that might cause less risk; Category D substances that can cause barely noticeable danger.

Ships built after 1986, carrying dangerous chemicals indicated in the IBC Code, must comply with its requirements in terms of design, construction and ship operation.

\subsection{International Code for the Construction and Equipment of Ships Carrying Liquefied Gases in Bulk, IGC Code}

The IGC Code was adopted with IMO Resolution MSC.5(48) on 17 June 1983.The IGC code applies to gas carriers constructed on or after 1 July 1986. Gas carriers constructed before that date should comply with the requirements of the Code for the 
Construction and Equipment of Ships Carrying Liquefied Gases in Bulk or the Code for Existing Ships Carrying Liquefied Gases in Bulk. ${ }^{20}$ The purpose of these codes is to establish an international standard for the safe marine transportation of liquefied gases and certain other substances in bulk, by proscribing design and construction standards for ships involved in such transport and the equipment required to minimize risks to the ship, its crew and the environment, having regard to the nature of the products involved.

The underlying philosophy is that of ship types related to the hazards of products covered by these codes, each of which may have one or more dangerous properties. Further hazards are associated with products transported under cryogenic (refrigerated) or pressurized conditions. Severe collisions or strandings may damage the cargo tank, causing an uncontrolled release of the product. Such release could cause the product to evaporate or disperse and, in some cases, cause brittle fracture of the ship's hull. The requirements in the codes are intended to minimize these risks as much as practicable, using our current know-how and technology.

According to section C of Chapter VII of the SOLAS Convention, provisions of the IGC Code are mandatory for all members of the SOLAS Convention. To account for ever evolving techniques and technologies, its amendments are taken into consideration as well. Its amendments were adopted with Resolution MSC.30 (61) on 11 December 1992. The IGC Code published in 1993 included the said amendments.

\subsection{International Code for the Safe Carriage of Packaged Irradiated Nuclear Fuel, Plutonium and High Level Radioactive Wastes on Board Ships, INF Code}

Ships carrying packaged irradiated nuclear fuel, plutonium and high-level radioactive waste must comply with the requirements of the INF code. The INF code defines the cargo covered, and provides specifications for ships carrying such cargo. ${ }^{21}$ The Code was adopted with Resolution MSC.88 (71) on 27 may 1999. Its application became mandatory as of 1 January 2001 based on amendments to Chapter VII of the SOLAS, entitled Carriage of dangerous goods.

20. Gas carriers constructed before that date should comply with the requirements of the Code for the Construction and Equipment of Ships Carrying Liquefied Gases in Bulk or the Code for Existing Ships Carrying Liquefied Gases in Bulk.

21. According to the Code, INF cargoes are packaged irradiated nuclearfuel, plutonium, high-level radioactive wastes in accordance with class 7 of the IMDG Code. Irradiated nuclear fuel - material containing uranium, thorium and/or plutonium isotopes used to maintain a self-sustaining nuclear chain reaction. Plutonium - the resultant mixture of isotopes of that material extracted from irradiated nuclear fuel from reprocessing. High-level radioactive wastes - liquid wastes resulting from the operation of the first stage extraction system or the concentrated wastes from subsequent extraction stages, in a facility for reprocessing irradiated fuel, or solids into which such liquid wastes have been converted.
The INF code applies to all ships regardless of the date of their construction or size, including cargo ships of less than 500 gross tonnage, engaged in the carriage of INF cargo. The INF Code does not apply to warships, naval auxiliary or other ships used only for governmental non-commercial purposes, although administrations are expected to ensure the compliance of such ships with the Code.

Special provisions of the Code regulate issues like, inter alia: damage stability, fire protection, temperature control of cargo spaces, structural considerations, cargo securing arrangements, electrical supplies, radiological protection equipment and management, training and shipboard emergency plans.

Ships carrying INF cargo are classified into one of three classes, depending on the level of radioactive cargoes carried. The INF Code classifies ships as belonging to Class INF 1, INF 2 or INF $3 .{ }^{22}$ Prior to the beginning of the journey, the ships are required to undergo basic inspection, which includes a detailed inspection of their structure, equipment, appliances and builtin materials. Once the competent authority finds that the results of the conducted inspection are satisfactory, it issues the International Certificate of Fitness for the Carriage of INF Cargo.

The INF Code regulates the issue of ship's stability under load. It, also, proscribes that every INF ship is required to have a Shipboard Emergency Plan. The plan must contain: worked out procedure for reporting accidents involving a ship carrying INF cargo, which the master or officer on duty are obligated to comply with; the list of authorized persons to be informed of the accident; a detailed description of activities to be taken by the person on board without delay, in order to prevent, reduce or control the release of hazardous substances; the method of contacting the ship to facilitate the coordination of work between the ship and the local authorities.

\subsection{International Management Code for the Safe Operation of Ships and for Pollution Prevention, ISM Code}

In October 1989, the IMO adopted, with Resolution A.647(16), Guidelines on Management for the Safe Operation of Ships and for Pollution Prevention. The purpose of the Guidelines is to ensure safety, protect people from harm or loss of life and avoid possible damage to the maximum extent possible. The Guidelines are based on general principles intended to support

22. Class INF 1 ship - ships certified for the carriage of INF cargo with the aggregate activity under 4,000 TBq (TeraBecquerel = measurement of radioactivity); Class INF 2 ship - ships certified for the carriage of irradiated nuclear fuel or high-level radioactive wastes with the aggregate activity under $2 \times 106$ TBq and ships certified for the carriage of plutonium with the aggregate activity under $2 \times 105$ TBq; and Class INF 3 ship - ships certified for the carriage of irradiated nuclear fuel or highlevel radioactive wastes and ships certified for the carriage of plutonium with no restriction of the maximum aggregate activity of the materials. 
development and management practices in the industry as a whole. The Guidelines have recognized the importance of the existence of international instruments for the safe operation of ships, as one of the most important factors for the prevention of maritime accidents and marine pollution.

In 1993, following a brief experience with the application of the Guidelines, the IMO adopted the ISM Code with Resolution A741 (18). After several years of practical experience, its importance and the need for it to become mandatory were recognized. It was decided that the best way to effect this was to amend the SOLAS Convention. Consequently, new chapter IX, entitled Management for the Safe Operation of the Ship, which consists of six rules, was added to the SOLAS Convention. Although the ISM Code was not incorporated into Chapter IX, the Chapter provides for its mandatory application..$^{23}$ The ISM Code entered into force and became mandatory for ships in 1998. In 1995, striving to ensure uniformity in the application of the ISM Code, the IMO adopted the Guidelines on the Implementation of the International Safety Management (ISM) Code by Administrations with Resolution A. 788 (19). These are the Guidelines for the implementation of the requirements of Chapter IX of the SOLAS and the ISM Code. The Guidelines were first revised in November 2001 with Resolution A.913 (22), and again in December 2009 with Resolution A.1022 (26). ${ }^{24}$

The ISM Code indicates that its requirements may apply to all ships. ${ }^{25}$ However, Rule 2 of Chapter IX of the SOLAS Convention states that the ISM Code applies to the following ships: cruise ships, including high speed cruise ships, built before 1 July 1998; tankers, chemical tankers, gas carriers, bulk cargo carriers and high speed carriers of 500 gross tonnage or more, built before 1 July 1998; other cargo ships and mobile offshore drilling units (MODUs) of 500 gross tonnage or more, built before 1 July 2002.

The ISM Code introduced a system for the safe operation (conduct) of ships (Safety Management System), the so called SMS system. Shipping companies are required to implement the system, and use it in all actions relating to planning, organization and execution of the tasks of the shipping company and of the ship on the mainland and at sea. The SMS system covered the ship and the company in accordance with the ISM Code for the first time.

The ISM Code clearly states that the SMS system should ensure the observance and compliance with rules, regulations

23. Rule 3.1. of Chapter IX of the SOLAS Convention.

24. In order to better understand and implement the ISM Code, certain guidelines have been adopted, such as: Guidelines for the operational implementation of the International Safety Management Code by Companies, MSC-MEPC.7/Circ.5; Guidance on the qualifications, training and experience necessary for undertaking the role of the designated person under the provisions of the International Safety Management Code, MSC-MEPC.7/Circ.6; Guidance on near-miss reporting, MSCMEPC.7/Circ.7. ISM Code and Guidelines on implementation of ISM Code, IMO, 2010.

25. Rule 1.3. of the ISM Code. and guidelines; the applicability of many regulations (the Codes); taking into account the recommended standards of various organizations, administrations, classification societies and the entire maritime industry.

The ISM Code proscribes functional requirements for the SMS system. It points out that every company should develop, implement and enforce the SMS system, together with the following requirements: safety of navigation and environmental protection policy; guidelines and procedures for the ship's safe navigation and environmental protection; determining the levels of authority and means of communication between the coast and the crew on board; procedures for reporting accidents and non-conformities of the established system with the ISM Code; procedures for emergency situations; internal control procedures and inspections of compliance with the established ISM Code; registration system for passenger data. ${ }^{26}$

To ensure the safe operation of each ship and communication between the company and persons onboard, the company should identify a specific person or persons ashore having direct access to the highest levels of management (Designated Persons Ashore-Dpa). This person is responsible for monitoring the safety of each ship, environmental protection and ensuring appropriate supporting resources from the mainland.

The ISM Code stipulates that the company is responsible for the implementation of its requirements. In this case, the term "company" means the shipowner or any other organization or person such as the Manager, or Bareboat Charterer, who took over the responsibility for a ship's operation from the shipowner and agreed to take over all the duties and responsibilities imposed by the Code. ${ }^{27}$ In this sense it is pointed out that:

The Company should ensure:

- That the shipmaster is properly qualified for assuming commanding and fully aware of the company's SMS system.

26. In Montenegro, the provisions on the safety management system for ships are provided in Article 50 of the Act on Safety of Maritime Navigation. The Article clearly states that the shipowner, i.e. the company is obliged to apply and maintain a safety management system, in accordance with the SOLAS Convention (Chapter IX) and the ISM Code, containing the following: a safety of navigation and environmental protection policy; instructions and procedures for the safe navigation of the ship and protection of the environment; define the levels of authorization and methods of communication between the coast and the crew onboard; procedures for reporting incidents and non-conformities of the established system with the ISM Code; procedures for emergency situations; procedures for internal control and inspections of functioning of the established ISM Code; system for registration of passengers. Paragraph 2 of the same Article stipulates that, to ensure the safe navigation of their vessels and communication between the company and persons onboard, the shipowner i.e. the company are obliged to appoint a person on the coast responsible for monitoring the safety of navigation of ships and protection of the environment.

27. Article 6, item 14 of the Act on Safety of Maritime Navigation of Montenegro, gives the definition of the term "company". A company means owner of the ship or another physical or legal person (manager, or charterer) who takes over the responsibility for ship navigation in accordance with the International Safety Management Code. 
The company is also required to provide the shipmaster with assistance he requires to safely execute his duties:

- That each ship is managed by a qualified, authorized and medically fit crew, in compliance with national and international requirements;

- That procedures ensuring that any new staff and staff transferred to new duties are familiar with the issue of safety and environmental protection are in place. Basic guidelines must be established and implemented prior to departure and appropriate documentation in this respect issued;

- That any personnel involved in the company's SMS fully understands the rules, regulations, policies and guidelines;

- That procedures are implemented, identify additional training required to improve the SMS system and ensure the implementation of such training and participation of the entire staff;

- The procedures for the receipt of necessary information on the SMS system by the ship's crew are available in their working language or a language they understand;

- That the crew is capable of and efficient in the execution of their duties pertaining to the SMS system.

The ISM Code sets forth the obligations of flag states. Namely, once a shipping company or a ship are established to have met the requirements of the ISM Code, i.e. that they have in place an SMS system compliant with the ISM Code, the competent administration of the flag state or another recognized authority (authority may be delegated to an organization, usually a classification society) issues: DOC (Document of Compliance), verifying that the SMS implemented by the shipping company is compliant with the ISM Code; Certificate of safe operation of the ship, the SMC (Safe Management Certificate) confirming that all ship operations are carried out in accordance with the SMS system.

The ISM regulations were amended in December 2000 with Resolution MSC.104 (73). The amendments came into force on 1 July 2002. In December 2004 with Resolution MSC. 179 (79). The amendments came into force on 1 July 2006. In May 2005 with Resolution MSC. 195 (80). The amendments came into force on 1 January 2009. The ISM Code was amended in December 2008 with Resolution MSC. 273 (85). The Resolution was adopted on January 1, 2010 and the amendments entered into force on 1 July 2010.

\section{CONCLUSION}

From the legal perspective, safety is a requirement without which navigation is prohibited. As the leader in ensuring safe navigation, ever since its inception, the IMO has been striving to ensure the minimum conditions requisite for safe navigation and safe stay at sea by taking numerous actions and measures. The adoption of international instruments, conventions, i.e. codes, or more precisely, their implementation into national laws, is essential for the promotion of safe navigation. The IMO issued a number of international codes which might be said to supplement the international conventions. General regulations on the safe transportation of cargo, the CSS code and the IMSBC Code are of particular importance, followed by special regulations on the safe transportation of certain types of cargo, the International Grain Code and the TDC Code, as well as regulations relating to the transport of dangerous goods by sea - the IMDG Code, the IBC Code, the IGC Code and the INF Code. Flag states, i.e. shipping companies, are obliged to strictly adhere to the requirements of international instruments, i.e. codes, which actually form the basis of their legislation. To this end, the states should separately regulate a number of issues relating to the safe transportation of certain types of cargo in their national legislation, instead of referring to the application of international codes in principle. Special attention should thus be paid to the adoption of manuals that would regulate in detail the procedures for the safe handling of different types of cargo, followed by the organization of training and issuance of certificates for handling and transportation of various types of cargo, and introduction of restrictive measures into national law.

\section{REFERENCES}

Arroyo, D. W., (1991), International Maritime Conventions, Deventer, Netherlands: Kluwer Law and Taxation Publishers.

Boisson, P., (1999), Safety at Sea: Policies, Regulations \& International Law, Paris: Bureau Veritas.

Bolanča, D., (2002), Maritime Law In the Era of Globalisation-Universal Law or A Mixed Legal System?, Zbornik radova Pravnog fakulteta u Splitu, 67(3-4), pp. 333338

Bolanča, D., (1999), Pomorsko pravo (odabrane teme), Split: University of Split, Faculty of Law, Split.

Brodie, P., (2013), Dictionary of Shipping Terms, 6th Edition, Routledge: Informa Law from Routledge.

Chorley, L. and Giles, O. C., (1977), Shipping Law, 6th Edition, London: Pitman.

Christodoulou-Varotsi, I., (2009), Maritime Safety Law and Policies of the European Union and the United States of America: Antagonism or Synergy? Berlin Heidelberg: Springer.,

https://doi.org/10.1007/978-3-540-69874-6

Belamaric, G., (2012), ISM kodeks \& SMS standard, Split: Pomorski fakultet.

Grabovac, I., (2002), Doprinos nekih međunarodnih konvencija sigurnosti plovidbe, Pomorski zbornik, 40(1), pp. 429-444.

Grabovac, I., (1995), Hrvatsko pomorsko pravo i međunarodne konvencije, Split: Književni krug.

Grabovac, I., (2001), Pomorsko upravno i javno pravo, Split.

Grabovac I., (2009), International Contracts as a Base for Harmonizing Maritime Law - in Relation to the Law on Amendments to the Maritime Code, 2008, Collection of Works of the Faculty of Law in Split, 46 (2), pp. 261 - 269. 
Ivošević, B., (2008), Saobraćajno pravo, Beograd: Pravni fakultet, Univerzitet UNION.

Kristiansen, S., (2013), Maritime Transportation: Safety Management and Risk Analysis, New York: Routledge.

Kiperaš, Ž., (1996), ISM kodeks - Primjena od strane države zastave, Uporedno pomorsko pravo, 38(149-152), pp. 73-82.

Kopacz, Z., Morgas, W. and Urbanski, J., (2001), The Maritime Safety System, its Main Components and Elements, The Journal of Navigation, 54(2), pp. 199-211. https://doi.org/10.1017/S0373463301001205

Nikčević Grdinić, J., (2015), Legal Regulations in the Function of Ensuring Ship Safety, Pomorstvo: Scientific Journal of Maritime Research, 29(1), pp. 30-39.

Nikčević Grdinić, J., (2012), Safe Transport of Dangerous Goods by Sea, Import Part of the Maritime Transport, Proc. 5th International Conference on Maritime Transport, Barcelona, Spain, June 27 - 29, pp.1038-1056.

Nikčević Grdinić J., (2016), Pravni aspekti pomorske sigurnosti, Beograd: Institut za pomorsko pravo.

Li, K. X. and Ng, J. M., (2002), International Maritime Conventions: Seafarers' Safety and Human Rights, Journal of Maritime Law \& Commerce, 33(3), pp. 381-395.
Luttenberger, A., (2005), Postupak donošenja i oživotvorenja konvencija iz pomorske sigurnosti Medjunarodne pomorske organizacije, Zbornik radova Pravnog fakulteta u Splitu, 42(1-2), pp. 399-407.

Milošević Pujo, B., (2006), Pomorsko pravo (Odabrane temo po STCW konvenciji), Dubrovnik: Sveučilište u Dubrovniku.

Pavić, D., (2001), Pravni učinci primjene ISM kodeksa na ograničenje odgovornosti brodara, Uporedno pomorsko pravo, 40(155), pp. 57-70.

Ringbom, H., (2008), European Union Maritime Safety Policy and International Law, vol. 64. Boston: Koninklijke Brill NV.

Rothblum, A., (2000), Human Error and Maritime Safety, Maritime Human Factors Conference, Linthicum, MD, March 13 - 14.

Yang, Z. L., Wang, J. and Li, K. X., (2013), Maritime safety analysis in retrospect, Maritime Policy \& Management, 40(3), pp. 261-277., http://dx.doi.org/10.1080/03088839.2013.782952

Zec, D., (2001), Sigurnost na moru, Rijeka: Pomorski fakultet u Rijeci.

Weintrit, A., (2009), Marine navigation and safety of sea transportation, CRC Press. https://doi.org/10.1201/9780203869345 